\title{
JPEB
}

Jurnal Penelitian Ekonomi dan Bisnis, 3 (1), 2018, Hal : 1 - 11

http://www.jpeb.dinus.ac.id

\section{ANALISIS PERSEPSI MAHASISWA TERHADAP NIAT MELAKUKAN WHISTLEBLOWING}

\author{
Sukma Indra* \\ Fakultas Ekonomi dan Bisnis Universitas Tanjungpura \\ JL. Prof. Dr. H. Hadari Nawawi Pontianak, Indonesia \\ *Corresponding Author: sari.ruslan99@gmail.com
}

Diterima: November 2017; Direvisi: Januari 2018; Dipublikasikan: Maret 2018

\begin{abstract}
This study examines students 'perceptions of students' intentions to conduct whistleblowing. This study was conducted with 400 respondents in the Faculty of Economics and Business at the University of Tanjungpura. By doing koesioner spread. The findings of this study are student perceptions which are viewed from 3 variables which are independent variables, namely attitudes toward behavior, subjectivity norms and perceptions of organizational support have a positive influence on students' intention to conduct whistleblowing. This research is expected to be additional information about students' perceptions in viewing whistleblowing actions and can also contribute to the development of social exchange theories that are more understandable especially by students.
\end{abstract}

Keywords : Whistleblowing; Intention; Perception; Students

\begin{abstract}
ABSTRAK
Penelitian ini mengkaji tentang persepsi mahasiswa terhadap niat mahasiswa untuk melakuan whistleblowing. Penelitian ini dilakukan dengan responden mahasiswa di lingkungan Fakultas Ekonomi dan Bisnis Universitas Tanjungpura sebanyak 400 orang. Dengan melakukan penyebaran koesioner. Temuan dari penelitian ini adalah persepsi mahasiswa yang dilihat dari 3 variabel yang menjadi variabel bebas yaitu sikap terhadap perilaku, norma subjekti dan persepsi dukungan organisasi memiliki pengaruh yang positif terhadap niat mahasiswa untuk melakukan whistleblowing. Penelitian ini diharapkan dapat menjadi informasi tambahan mengenai persepsi mahasiswa dalam memandang tindakan whistleblowing dan juga dapat memberi kontribusi untuk pengembangan teori pertukaran sosial yang lebih bisa dipahami khususnya oleh mahasiswa.
\end{abstract}

Kata Kunci : Whistleblowing; Niat; Persepsi; Mahasiswa 


\section{PENDAHULUAN}

Whistleblowing adalah pelaporan yang dilakukan oleh anggota organisasi (aktif maupun nonaktif) mengenai pelanggaran, tindakan ilegal atau tidak bermoral kepada pihak di dalam maupun di luar organisasi.Seseorang yang melakukan whistleblowing disebut pelapor pelanggaran sebagai whistleblower (Semendawai, et, al., 2011). Setiap orang bisa menjadi whistleblower, namun untuk menjadi seorang whistleblower bukanlah pekara yang mudah. Dibutuhkan keberanian dan keyakinan untuk melakukannya. Seseorang yang berada dalam sebuah organisasi atau instansi umumnya akan menghadapai dilema etis dalam memutuskan apakah harus mengungkapkan atau membiarkannya. Di satu sisi sebagian orang mungkin memandang whistleblower sebagai penghianat perusahaan karena telah mengungkap rahasia perusahaan, di satu sisi lainnya sebagian memandang whistleblower sebagai pelindung heroik yang menjunjung tinggi terhadap nilai-nilai moral yang dianggap lebih penting dari loyalitas kepada organisasi (Bagustianto \& Nurkholis, 2015). Hal ini dikarenakan seorang whistleblower tidak menutup kemungkinan akan mendapatkan teror dari oknum-oknum yang tidak menyukai keberadaannya. Seperti contoh kasus Novel Baswedan yang sering menghiasi layar kaca pertelevisian baru-baru ini, penyidik KPK Novel Baswedan disiram air keras oleh dua orang yang belum diketahui saat Novel baru pulang sholat subuh berjamaah di masjid dekat rumahnya. Salah satu dugaan Novel Baswedan di siram air keras terkait dengan kasus besar yang tengah ditangani Novel di KPK yakni dengan kasus e-KTP.

Seorang whistleblower di negara barat rata-rata dijadikan role model/panutan (Vinten, 1992 dalam Malik 2010) atas tindakan berani mereka melaporkan tindakan tidak etis atau ilegal walaupun hal tersebut memberikan risiko yang besar terhadap karir pekerjaannya, kehidupan pribadi, maupun mental outlook terhadap mereka. Sejak awal 1990an banyak negara didunia telah membuat peraturan perundang-undangan korporasi, undangundang ketenaga kerjaan, undang-undang konsumen dan keuangan. Negara-negara ini antara lain Amerika Serikat, Australia, Kanada, Perancis, India, Jepang, Selandia Baru, dan Inggris (Semendawai, et., al. 2011).

Penelitian tentang whistleblowing sudah banyak dilakukan baik di luar negeri maupun di Indonesia. Beberapa penelitian memberikan hasil yang berbeda-beda, seperti Park et al., (2008) yang melakukan penelitian terhadap sikap mahasiswa Korea Selatan, Turki dan Inggris menemukan bahwa terdapat perbedaan sikap antara mahasiswa di negara yang berbeda tersebut terhadap whistleblowing. Namun pada penelitiannya yang lain, dengan memasukkan variabel teori perilaku terencana Park dan Blenkinsopp (2009) menemukan bahwa sikap, norma subyektif dan persepsi kontrol perilaku berpengaruh signifikan terhadap niat whistleblowing.

Sementara penelitian whistleblowing yang dilakukan di Indonesia, pernah dilakukan oleh Sulistomo (2012), Daivitri (2012), Malik (2010) dan Mellisa, et. al., (2017) persepsi dan pengaruhnya terhadap niat melakukan whistleblowing. Hasil penelitian tersebut menunjukkan bahwa persepsi tentang norma subyektif, sikap, dan persepsi tentang kontrol perilaku berpengaruh positif terhadap niat mahasiswa melakukan pengungkapan kecurangan. Penelitian ini merupakan replikasi dari penelitian sebelumnya yang membedakannya pada penelitian ini sampel yang menjadi responden bukan hanya mahasiswa dari jurusan akuntansi saja melainkan mahasiswa jurusan lain juga yang ada di FEB Untan. Berdasarkan penjabaran sebelumnya peneliti merasa perlu untuk mengetahui persepsi mahasiswa dalam melakukan tindakan whistleblowing. Penelitian ini diharapkan dapat memberikan kontribusi bagi pengembangan teori pertukaran sosial dalam melakukan tindakan whistleblowing.

\section{TINJAUAN PUSTAKA}

Whistleblowing merupakan sebuah proses yang kompleks dimana melibatkan faktor pribadi dan organisasi. Kebanyakan penelitian menunjukan bahwa karyawan yang lebih tua 
dan lebih berpengalaman memeiliki kecenderungan yang lebih tinggi untuk melakukan whistleblowing. Hal ini dikarenakan semakin berpengalaman seseorang maka makin berkomitmenlah mereka kepada organisasi tempat mereka bekerja (Near \& Miceli, 1985). Dengan demikian, muncul niat untuk melaporkan kecurangan yang dapat membahayakan keberadaan organisasi mereka.

Istilah whistleblowing ini muncul sejak adanya Sarbanes Oxley Act 2002 (SOX) di Amerika Serikat yang dapat mendorong para pegawai dari perusahaan untuk melakukan pelaporan atas tindakan kecurangan atau pelanggaran yang terjadi tanpa ada rasa takut terhadap pihak yang dilaporkan.

Menurut Ajzen (2005), sikap adalah disposisi untuk merespon secara favorable atau unfavorable terhadap benda, orang, intansi atau kejadian. Menurut Assael (2001) sikap terhadap perilaku didefinisikan kecenderungan yang dipelajari untuk memberikan respon kepada obyek atau kelas obyek secara konsisten baik dalam rasa suka maupun tidak suka. Sedangkan menurut Mowen dan Minor (2002) sikap terhadap perilaku merupakan perasaan terhadap sebuah rangsangan. Berdasarkan dua definisi di atas sikap terhadap perilaku dapat didijelaskan bahwa sikap terhadap perilaku sebagai kecenderungan yang dipelajari untuk memberi respon atau menerima rangsangan terhadap obyek secara konsisten baik dalam rasa suka maupun tidak suka.

Sikap terhadap perilaku bukanlah sebuah perilaku, namun sikap terhadap perilaku merupakan suatu kesiapsiagaan untuk tindakan yang mengarah pada perilaku (Assael, 2001). Seorang individu akan melakukan sesuatu sesuai dengan sikap yang dimilikinya terhadap suatu perilaku. Sikap terhadap perilaku yang dianggap positiflah yang nantinya akan dipilih individu untuk berperilaku dalam kehidupannya. Oleh karena itu, sikap terhadap perilaku merupakan suatu wahana dalam membimbing seorang individu untuk berperilaku.

Norma Subyektif adalah pengaruh sosial yang mempengaruhi seorang individu untuk berperilaku. Seorang individu akan memiliki keinginan terhadap suatu obyek atau perilaku jika seandainya ia terpengaruh oleh orang-orang yang ada di sekitarnya untuk melakukannya atau ia meyakini bahwa lingkungan atau orang-orang disekitarnya mendukung terhadap apa yang ia lakukan. Hogg dan Vaughan (2005) yang dikutip dalam Parianti et. al., (2016) menyatakan bahwa norma subyektif adalah produk dari persepsi individu tentang kepercayaan/keyakinan yang dimiliki orang lain. Norma subyektif yaitu keyakinan individu untuk mematuhi arahan atau anjuran orang di sekitarnya untuk turut dalam melakukan aktifitas.

Ajzen (1991) mengartikan niat sebagai disposisi tingkah laku, yang hingga terdapat waktu dan kesempatan yang tepat, akan diwujudkan dalam bentuk tindakan. Niat juga diartikan sebagai deklarasi internal untuk bertindak/melakukan sesuatu (Hogg dan Vaughan, 2005 yang dikutip dalam Parianti et. al,. 2016).

Teori lain yang digunakan adalah teori pertukaran sosial, dimana Cropanzano dan Mictchell (2005) menjelaskan bahwa dasar dari teori pertukaran sosial adalah hubungan yang meningkat dari waktu ke waktu dimana akan menjadi hubungan yang saling mempercayai, loyal, dan saling berkomitmen selama kedua belah pihak menaati aturan-aturan pertukaran. Peraturan mengenai pertukaran umumnya melibatkan hubungan timbal balik atau aturan membayar kembali dalam bentuk tindakan dari suatu pihak sebagai respon dari tindakan pihak lain (Cropanzano \& Mictchell, 2005). Pedekatan pertukaran sosial mengintegrasikan keyakinan seorang individu tentang bagaimana seorang individu tersebut diperlakukan oleh organisasinya dan bagaimana organisasi berkomitmen kepada mereka (Eisenberger et al., 1986). Dengan demikian, jika seorang individu percaya bahwa organisasi berkomitmen kepadanya maka seorang individu tersebut juga akan berkomitmen kepada organisasi. Jadi, dapat disimpulkan bahwa teori pertukaran sosial menjadi teori yang mendukung terjadinya niat melakukan tindakan whistleblowing. 
Penelitian Sulistomo (2012) niat nerupakan keinginan kuat untuk melakukan sesuatu yang muncul dari dalam diri setiap individu.Niat dapat dihubungankan dengan motivasi seseorang untuk melakukan suatu tindakan. Jika tindakan tersebut dilakukan terus menerus, maka akan menciptakan suatu pribadi dengan perilaku yang dilakukannya secara terus menerus. Selain itu, hasil penelitiannya menunjukkan bahwa semakin mahasiswa memiliki persepsi lingkungan mahasiswa mendukungnya, dan sikap positif terhadap perilaku pengungkap kecurangan serta memiliki persepsi bahwa perilaku yang ditunjukkan nantinya merupakan hasil control diri sendiri dapat mempengaruhi mahasiswa akuntansi untuk memiliki niat mengungkap kecurangan.

Mellisa et. al (2017), hasil penelitiannya menunjukkan pentingnya menunjukkan pentingnya etika dalam penyusunan kurikulum dan sistem pembelajaran, serta pentingnya teladan dari perilaku etis dosen dan lingkungan perkuliahan yang positif. Sementara, hasil penelitian Parianti et. al (2016) menunjukkan bahwa jika mahasiswa menunjukan niat yang tinggi untuk melaporkan kecurangan cenderung akan melaporkan kecurangan yang ditemukannya dibandingkan dengan mahasiswa yang menunjukkan niat yang rendah.

\section{Kerangka Konseptual}

Kerangka konseptual ini dimaksudkan untuk melihat potensi niat mahasiswa untuk melakukan whistleblowing dengan pelihat sikap terhadap perilaku mahasiswa, norma subyektif mahasiswa dan dukungan organisasi yang mahasiswa rasakan, sehingga tujuan dari penelitian ini dapat terjawab. Selain itu, untuk menjawab ini maka terdapat tiga hipotesis dari penelitian ini, yaitu :

$\mathrm{H}_{1}$ : Sikap terhadap perilaku berpengaruh positif terhadap niat mahasiswa untuk melakukan whistleblowing

$\mathrm{H}_{2}$ : Norma subyektif berpengaruh positif terhadap niat mahasiswa untuk melakukan whistleblowing.

$\mathrm{H}_{3}$ : Persepsi dukungan organisasi berpengaruh positif terhadap niat mahasiswa untuk melakukan whistleblowing.

Penelitian ini menggambarkan kerangka konseptual sebagai berikut :

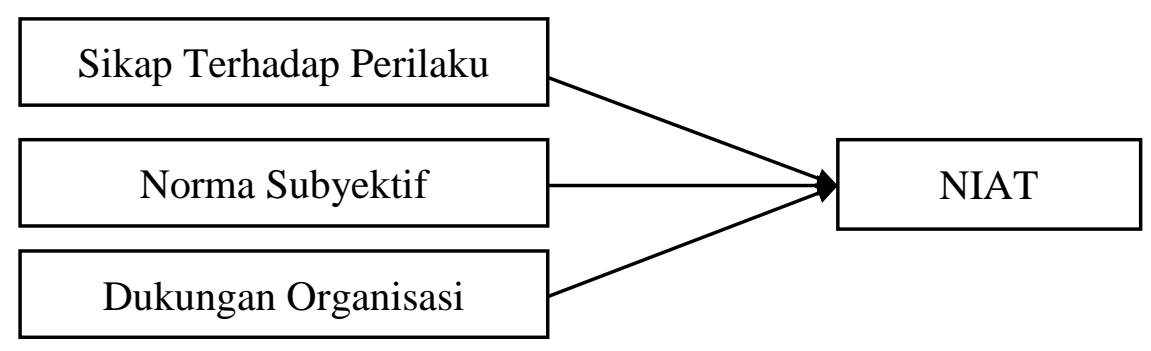

\section{Gambar 1. Kerangka Konseptual}

\section{METODE PENELITIAN}

Penelitian ini menggunakan metode deskriptif, dimana dalam penelitian ini berusaha untuk mendeskripsikan fenomena-fenomena yang terjadi di sekitar obyek penelitian, dengan maksud untuk mencari jalan penentuan penelitian lebih lanjut ataupun sekedar mencari tahu peristiwa yang terjadi sesungguhnya atau berupaya untuk memperoleh deskripsi yang lengkap dan akurat dari suatu situasi.Selanjutnya data dianalisis baik secara kuantitatif maupun kualitatif. 
Penelitian ini menggunakan data primer dengan teknik pengambilan data purposive sampling. Data diambil dengan cara menyebarkan 400 koesioner kepada mahasiswa di lingkungan FEB UNTAN. Di samping itu juga dipelajari dari dokumen - dokumen atau literature untuk pengayaan data.

Variabel dependen merupakan variabel yang dipengaruhi atau menjadi akibat, karena adanya variabel independen (Sugiyono, 2013). Variabel independen dalam penelitian ini adalah :

1. Sikap terhadap perilaku

Sikap terhadap perilaku adalah penilaian seseorang ketika melihat atau mengetahui suatu perilaku yang dilakukan. Seseorang akan memberikan suatu penilaian terhadap perilaku yang dilakukan seseorang. Penilaian yang diberikan dapat berupa hal yang positif maupun negatif.

2. Norma Subyektif

Norma subyektif adalah norma yang dihasilkan seseorang berdasarkan norma yang ada disekitarnya. Ajzen (1991) mendefinisikan norma subyektif sebagai tekanan yang dirasakan untuk melakukan atau tidak melakukan perilaku. Seseorang akan memiliki suatu norma yang diyakini dirinya sendiri. Tetapi, norma yang diyakininya tersebut memiliki pengaruh dari norma yang ada disekitar orang tersebut.

3. Dukungan Organisasi

Dukungan organisasi adalah keyakinan seorang individu mengenai penghargaan dukungan, dan perhatian yan diberikan organisasi atas kontibusi yang telah diberikan seorang individu serta kepedulian oganisasi terhadap kesejahteraan anggotanya (Eisenberger et al., 1986).

4. Niat

Niat adalah suatu keadaan dimana seseorang ingin melakukan suatu perilaku.

Metode analisis data menggunakan SPSS versi 23 yang dijalankan dengan media komputer. Teknik statistika multivarian yang dilakukan perbandingan antara variabel dependen dengan variabel independen dengan regresi liner berganda. Dimana akan membentuk persamaan regresi sebagai berikut :

$$
Y=a_{0}+a_{1} X_{1}+a_{2} X_{2}+a_{3} X_{3}+e
$$

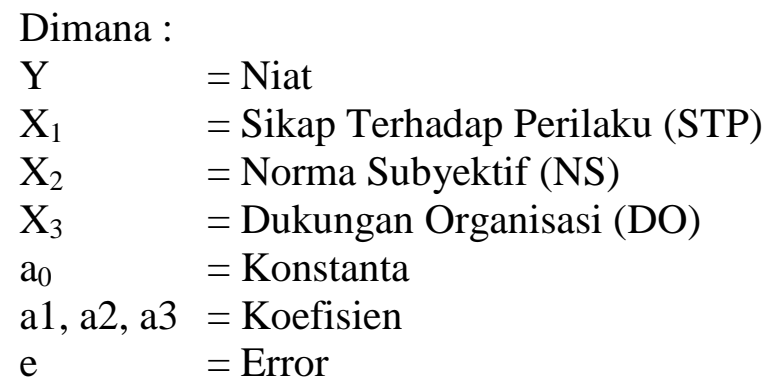

\section{HASIL DAN PEMBAHASAN}

Penelitian ini dimulai dengan melakukan penyebaran kuesioner kepada responden yaitu mahasiswa Fakultas Ekonomi dan Bisnis Universitas Tanjungpura angkatan 2014 dan 2015.Penyebaran kuesioner dilakukan secara langsung kepada responden di Fakultas Ekonomi dan Bisnis Universitas Tanjungpura. 
Tabel 1. Tingkat Pengembalian Kuesioner

\begin{tabular}{lc}
\hline \multicolumn{1}{c}{ Keterangan } & Jumlah \\
\hline Kuesioner yang disebar & 400 \\
Kuesioner yang kembali dari responden & 346 \\
Kuesioner yang tidak diisi lengkap & 17 \\
Kuesioner yang dapat diolah & 329 \\
Tingkat pengembalian kuesioner (respon rate) & $91,6 \%$ \\
\hline
\end{tabular}

Koesioner disebarkan sebanyak 400 koesioner, namun yang kembali sebanyak 346 koesioner dan yang tidak lengkap pengisian koesioner dasa sebanyak 17 koesioner ehingga data yang dapat diolah sebanyak 329 untuk menganalisis permasalahan dalam penelitian ini. Selanjutnya disajikan karakteristik dari responden dalam penelitian ini.

Jumlah responden mahasiswa reguler A sebanyak 190 orang atau $61,14 \%$ dan mahasiswa reguler B sebanyak 139 orang atau 39\%. Responden dalam penelitian ini dilakukan kepada mahasiswa angkatan 2014 dan 2015, dimana mahasiswa angkatan 2014 sebanyak 155 orang atau 45,85\% dan mahasiswa angkatan 2015 sebanyak 124 orang atau $54,15 \%$.

Berikut ini adalah hasil pengolahan data untuk melihat pengaruh antara variabel terikat dengan variabel-variabel bebas sehingga dapat terbentuk persamaan regresi linier berganda dari penelitian ini.

Tabel 2. Hasil Regression Analysis

\begin{tabular}{llrrrr}
\hline & \multicolumn{2}{c}{ Unstandardized Coefficients } & & \\
\cline { 2 - 3 } Model & \multicolumn{1}{c}{$\mathrm{B}$} & \multicolumn{2}{c}{ Std. Error } & $\mathrm{t}$ & \multicolumn{1}{c}{ Sig. } \\
\hline 1 & (Constant) & 2.806 & 1.476 & 1.901 & .059 \\
& STP & .163 & .075 & 2.160 & .032 \\
NS & .326 & .054 & 6.044 & .000 \\
DO & .313 & .068 & 4.584 & .000 \\
\hline
\end{tabular}

a. Dependent Variable: Niat

Berdasarkan output pada tabel 6 di atas maka dapat dibuat persamaan sebagai berikut:

$$
\mathrm{DA}=2,806+0,163 \mathrm{STP}+0,326 \mathrm{NS}+0,313 \mathrm{DO}+\mathrm{e}
$$

Persamaan di atas maka dapat disimpulkan bahwa:

1. Nilai koefisien dari Sikap Terhadap Perilaku (SPT) sebesar 0,163, hal ini menunjukkan bahwa SPT memiliki pengaruh ke arah positif terhadap Niat untuk melakukan whistleblowing. Artinya semakin kuat sifat mahasiswa terhadap perilaku pandangannya terhadap kecuranganmaka niat untuk melakukan atau sebagai whistleblowing semakin meningkat.

2. Nilai koefisien dari Norma Subjektif (NS) sebesar 0,326, hal ini menunjukkan bahwa Norma Subjektif yang dimiliki oleh mahasiswa memilki pengaruh ke arah positif terhadap niat mahasiswa untuk melakukan whistleblowing. Artinya semakin besar norma subjektif yang dimiliki mahasiswa maka niat mahasiswa untuk melakukan whistleblowing juga semakin meningkat.

3. Nilai koefisien dari Dukungan Organisasi (DO) sebesar 0,313, hal ini menunjukkan bahwa dukungan organisasi memiliki pengaruh ke arah positif terhadap niat mahasiswa untuk melakukan whistleblowing. Artinya semakin besar dukungan organisasi maka niat mahasiswa untuk melakukan whistleblowing semakin meningkat. 
Penelitian ini memiliki tiga hipotesis yang perlu dilakukan untuk pembuktian atau pengujian niat mahasiswa untuk melakukan whistleblowing. Adapun hasil dari uji hipotesis dalam penelitian ini adalah sebagai berikut :

Tabel 3. Hasil Pengujian Hipotesis

\begin{tabular}{clccc}
\hline No & \multicolumn{1}{c}{ Hipotesis $\left(\mathbf{H}_{\mathbf{a}}\right)$} & t- hit & Prob & $\begin{array}{c}\text { Keputusan } \\
\text { Hipotesis }\end{array}$ \\
\hline 1 & $\begin{array}{l}\text { Sikap terhadap perilaku berpengaruh } \\
\text { positif terhadap niat mahasiswa untuk } \\
\text { melakukan whistleblowing. }\end{array}$ & 2.160 & .032 & $\begin{array}{c}\mathrm{H}_{\mathrm{a} 1} \text { diterima } \\
\text { dan } \mathrm{H}_{\mathrm{o}} \text { ditolak }\end{array}$ \\
2 & $\begin{array}{l}\text { Norma subyektif berpengaruh positif } \\
\text { terhadap niat mahasiswa untuk melakukan } \\
\text { whistleblowing. }\end{array}$ & & & \\
3 & $\begin{array}{l}\text { Persepsi dukungan organisasi berpengaruh } \\
\text { positif terhadap niat mahasiswa untuk } \\
\text { melakukan whistleblowing. }\end{array}$ & 4.584 & .000 & $\begin{array}{c}\mathrm{H}_{\mathrm{a} 1} \text { diterima } \\
\text { dan } \mathrm{H}_{\mathrm{o}} \text { ditolak }\end{array}$ \\
\hline
\end{tabular}

Hasil uji hipotesis yang tampak pada tabel 8 menunjukkan bahwa ketiga hipotesis dalam penelitian ini dapat diterima. Karena ketiga hipotesis tersebut memiliki nilai signifikansi (porbabilitasnya) lebih kecil dari 0,05. Nilai t statistic dari ketiga variabel tersebut menunjukkan nilai positif, masing-masing variabel sebesar 2,160 untuk sikap terhadap perilaku terhadap niat mahasiswa untuk melakukan whitleblowing. Lalu 6,044 untuk norma subjektif yang dimiliki oleh mahasiswa terhadap niat dalam melakukan whistleblowing dan 4,584 untuk dukungan organisasi terhadap niat mahasiswa untuk melakukan whistleblowing.

Secara umum teori menyatakan bahwa seseorang akan mempunyai sikap positif terhadap suatu perilaku apabila berhubungan dengan tujuan yang positif. Whistleblowing merupakan suatu tindakan yang bertujuan positif, yaitu keinginan melaporkan kecurangankecurangan yang ada disuatu organisasi. Jadi, semakin seorang individu tersebut mempunyai pemikiran bahwa suatu tingkah laku akan memberikan efek positif maka individu tersebut akan cenderung bersikp favorable pada suatu perilaku, begitu juga sebaliknya, semakin individu mempunyai pemikiran bahwa suatu perilaku akan memberikan efek negatif maka seseorang individu akan cenderung bersikap unfavorable terhadap perilaku tersebut (Azjen, 2005).

Hipotesis pertama dalam penelitian ini yaitu "Sikap terhadap perilaku berpengaruh positif terhadap niat mahasiswa untuk melakukan whistleblowing." dapat diterima. Hasil ini memperkuat apa yang dikemukakan oleh Azjen (2005) dan sejalan dengan penelitian yang dilakukan oleh Azjen (1991), Parianti et. al.(2016) dan Saud, Ilham Maulana (2016) yang menjelaskan bahwa sikap terhadap perilaku berpengaruh positif terhadap niat untuk melakukan whistleblowing. Namun berbeda dengan hasil penelitian yang dilakukan oleh Mellisa et. al. (2017) yang menemukan bahwa sikap terhadap perilaku tidak berpengaruh positif terhadap niat untuk melakukan whistleblowing.

Selanjutnya hipotesis kedua dari penelitian ini juga dapat diterima, yaitu "Norma subyektif berpengaruh positif terhadap niat mahasiswa untuk melakukan whistleblowing." Hasil penelitian Ajzen (2005) yang mengemukakan ada pengaruh positif norma subyektif yang dimiliki mahasiswa yang ditunjukkan melalui tekanan sosial dari orang-orang disekelilingnya seperti teman, dosen dan orang tua terhadap niat mahasiswa (Ajzen, 2005) artinya penelitian ini sejalan dengan hasil penelitian yang dikemukakan Ajzen (2005). Selain itu, penelitian ini juga didukung oleh penelitian yang dilakukan oleh Sulistomo (2012), 
Parianti et. al. (2016) dan Mellisa et. al. (2017) yang menjelaskan bahwa norma subyektif berpengaruh positif terhadap niat untuk melakukan whistleblowing.

Beberapa lembaga publik di Indonesia telah memiliki sistem penanganan pengaduan (whistleblower system) dan sistem ini sudah mulai diberlakukan secara efektif. Indonesia sendiri memiliki masyarakat dengan budaya kolektif, yaitu kehidupan sosial menjadi lebih dominan dalam keseharian dibandingkan dengan kehidupan pribadi.

Dukungan organisasi yang dirasa individu memiliki hubungan dengan perasaan mudah atau tidak untuk melakukan sesuatu perbuatan.Tindakan whistleblowing salah satunya, karena tindakan tersebut dilakukan sesuai dengan sumber dan kesempatan yang dimiliki dan juga seberapa besar kemampuan untuk tidak melakukannya.Hal ini juga dapat dibuktikan dalam penelitian ini, dilihat dari hasil pengujian hipotesis yang menunjukkan bahwa dukungan organisasi berpengaruh positif terhadap niat mahasiswa untuk melakukan whistleblowing dapat diterima.

Hasil pengujian hipotesis yang ketiga ini sejalan dengan Adebayo (2005), Hooks et al., (1994), Kaplan, S.E. dan Whitecotton, S.M. (2001) yang menunjukan adanya hubungan antar tingkat dukungan organisasi dengan untuk mengungkapkan kecurangan. Namun berbeda dengan hasil penelitian yang dilakukan oleh Saud dan Maulana (2016) yang menemukan tidak ada pengaruh dari dukungan organisasi untuk melaporkan tindakan kecurangan.

Hasil penelitian ini sesuai dengan teori pertukaran sosial, ketika seseorang ingin melaporkan kecurangan dan meyakini bahwa tidak akan mendapat ancaman atau sanksi baik secara ekonomi maupun sosial dari organisasi, maka akan menimbulkan dampak positif terhadap niat untuk melakukan whistleblowing yang merupakan suatu tindakan yang bermanfaat bagi organisasi.

\section{SIMPULAN}

Ketiga hipotesis dalam penelitian ini dapat diterima. Sehingga ketiga variabel bebas dalam penelitian ini yaitu sikat terdapat perilaku $\left(\mathrm{X}_{1}\right)$, norma subyektif $\left(\mathrm{X}_{2}\right)$ dan dukungan organisasi $\left(\mathrm{X}_{3}\right)$ terbukti memiliki pengaruh positif terhadap niat mahasiswa untuk melakukan tindakan whistleblowing. Selain itu, hasil penelitian ini sesuai dengan teori pertukaran sosial yang mengungkapkan bahwa orang akan melakukan suatu tindakan yang tidak akan mengancam atau merugikan dirinya. Penelitian mengenai whistleblowing di masa mendatang diharapkan mampu memberikan hasil penelitian yang lebih berkualitas, dengan mempertimbangkan untuk menambah variabel yang mampu mempengaruhi perilaku whistleblowing seperti variabel demografi dan komitmen.

\section{DAFTAR PUSTAKA}

Adebayo, D. O. 2005. Ethical Attitudes And Prosocial Behaviour In The Nigeria Police : Moderator Effects Of Perceived Organizational Support And Public Recognition. Policing : An International. Journal of Police Strategies and Management, 28 (4): 684-705.

Ajzen, I. 1988. Attitudes, personaliQ, and behavior. Chicago, IL : Dorsey.

Ajzen, Icek. 1991. The theory of planned behavior. Organizational Behavior and Human Decision Processes. 50 (2) :179-211.

Ajzen, Icek. 2005. Laws of human behavior : symmetry, compatibility, and attitude behavior correspondence. in a. Beauducel, B. Biehl, M. Bosniak, W. Conrad, G. Schonberger, \& D. Wagener (Eds.), Multivariate Research Strategies (pp. 3-19). Aachen, Germany : Shaker Verlag.

Ajzen, I dan Fishbein M. 2010. Understanding Attitudes and Predicting Social Behaviour. Englewood Cliffs. NJ : Prentice Hall 
Alfani, Ulin Nuha. 2016. Persepsi Mahasiswa Akuntansi Terhadap Niat Melakukan Whistleblowing. Skripsi. Universitas Lampung.

Alleyne, P., M. Hudaib, R. Pike. 2013. Towardsa Conceptual Model of Whislteblowing Intention Among External Auditors. The British Accounting Review, 45: 10-23.

Assael, Henry. 2001. Consumer Behavior $6^{\text {th }}$ Edition. New York: Thomson-Learning.

Bagustianto, Rizki \& Nurkholis. 2012. Faktor-Faktor yang Mempengaruhi Minat Pengawai Negeri Sipil (PNS) untuk Melakukan Tindakan Whistleblowing (Studi pada PNS BPK $R I)$. e-jurnal Universitas Brawijaya.

Chiu, R.K., 2003. Ethical Judgment and Whsitleblowing Intention : Examining The Moderating Role of Locus of Control. Journal of Business Ethics..43: 65-74.

Carpenter, Tina D., and Jane L. Reimers. 2005. Unethical and Fraudulent Financial Reporting : Applying the Theory of Planned Behavior. Journal of Business Ethics. 60: 115-129.

Cropanzano, R. dan M. S. Mitchell. 2005. Social Exchange Theory: An Interdisciplinary Review. Journal of Management. 31: 874-900.

C. Mowen, John. Michael Minor. 2002. Perilaku Konsumen. Jakarta: Erlangga

Daivitri, A.A.I. Niyaratih. 2013. Pengaruh Pertimbangan Etis dan Komponen Perilaku Terencana pada Niat Whistleblowing Internal dengan Locus of Control sebagai Variabel Pemoderasi.Tesis. Program Pascasarjana Universitas Gadjah Mada : Yogyakarta.

Detik Com. 2008. Kasus kecurangan Urip Tri Gunawan. Diakses dari https://news.detik.com/berita/902725/kronologi-penangkapan-jaksa-urip Pada tanggal 10 Desember 2017

Destriana, Kurnia Kreshastuti. 2014. Analisis Faktor-Faktor Yang Mempengaruhi Intensi Auditor Untuk Melakukan Tindakan Whistleblowing (Studi Pada Kantor Akuntan Publik Semarang), Jurnal, Semarang : Undip.

Eisenberger, R., R. Huntington, S. Hutchinson, dan D.Sowa. 1986. Perceived organizational support. Journal of Applied Psychology 71(3): 500-507.

Elias. 2008. Auditing Student Professional Commitment and Anticipatory Socialization and Their Relationship to Whistleblowing, Managerial Auditing Journal. 23(3): 283-294.

Ghozali, Imam. 2015. Aplikasi Analisis Mulivariate dengan Progra IBM SPSS. Semarang: Badan Penerbit Universitas Diponegoro.

Herawaty,\& Yulius. 2008. Profesionalisme Pengetahuan Akuntan Publik Dalam Mendeteksi Kekeliruan, Etika Profesi Dan Pertimbangan Tingkat Materialitas". Trisakti school of management. Jakarta.

Hudson, Simon. 2008. Tourism And Hospitality Marketing : A Global Perspective. London : SAGE Publication Ltd.

Hussein, Ananda Sabil. 2015. Penelitian Bisnis dan Manajemen Menggunakan Partial Least Squares (PLS) dengan smartPLS 3.0. Modul Ajar. Universitas Brawijaya.

Hooks, et, al. 1994. Enhancing communication to assist in fraud prevention and detection. Auditing : A Journal of Practice \& Theory. 13 (2): 86-117.

Hwang, et. al. 2008. "Confucian Culture and Whistleblowing by Professional Accounting: an exploratary study”. Managerial Auditing Journal,. 23 (5):. 504-526

Ilham, Maulana Saud. 2016. Pengaruh Sikap dan Persepsi Kontrol Perilaku Terhadap Niat Whistleblowing Internal-Eksternal dengan Persepsi Dukungan Organisasi Sebagai Variabel Pemoderasi”. Jurnal Akuntansi dan Investasi. 17 (2): 209-219

Indriantoro, dan Supomo. 2002. Metodologi Penelitian Bisnis untuk Akuntansi dan Manajemen,. Yogyakarta: BPFE-Yogyakarta.

Jogiyanto. 2007. Sistem Informasi Keperilakuan. Yogyakarta: Penerbit Andi

Jogiyanto dan Abdillah. 2009. Konsep dan Aplikasi PLS (partial least square) untuk penelitian empiris. Yogyakarta : BPFE 
Jogiyanto, H. 2011. Konsep dan Aplikasi Structural Equation Modeling (SEM) Berbasis Varian dalam Penelitian Bisnis. Yogyakarta : STIM YKPN.

Jonathan, Sarwono. 2006. Metode Penelitian Kuantitatif dan Kualitatif. Yogyakarta : Graha Ilmu

Kaplan, S. E. dan S. M. Whitecotton. 2001. An examination of the auditors' reporting intentions when another auditor is offered client employment. Auditing : A Journal of Practice and Theory. 20 (1): 45-63.

Kamus Besar Bahasa Indonesia. 2015. Niat. Diakses dari http://kamusbahasaindonesia.org/niat.Pada tanggal 8 Septembet 2017.

Komite Nasional Kebijakan Governance (KNKG). 2008. Pedoman Sistem Pelaporan Pelanggaran-SSP (Whistleblowing System-WBS). Jakarta.

Kompas Nasional. 2008. Kasus kecurangan Burhanuddin Abdullah. Diakses dari http://nasional.kompas.com/read/2008/10/29/12144047/Burhanuddin.Abdullah.Divon is.Lima.Tahun.Pada tanggal 10 Desember 2017.

Kompas Nasional. 2011. Kasus kecurangan Muhammad Nazaruddin. Diakses dari http://indeks.kompas.com/topik-pilihan/list/2742/kasus.korupsi.akil.mochtar.Pada tanggal 10 Desember 2017.

Kompas Nasional. 2013. Kasus kecurangan Akil Mochtar. Diakses dari http://indeks.kompas.com/topik-pilihan/list/2742/kasus.korupsi.akil.mochtar.Pada tanggal 10 Desember 2017.

Kreshastuti, Destriana Kurnia. 2014. Analisis Faktor-Faktor Yang Mempengaruhi Intensi Auditor Untuk Melakukan Tindakan Whistleblowing (Studi Empiris Pada KAP Di Semarang). Journal Of Accounting.3 (2).

Kreitner dan Kinicki. 2005. Perilaku Organisasi. Jakarta : Salemba Empat.

Kuningsih, Reni Sekar. 2013. Faktor-Faktor Yang Mempengaruhi Niat Mahasiswa Akuntansi Untuk Berkarir Sebagai Akuntan Profesional. Skripsi. Semarang: Universitas Diponegoro.

Kuncoro, Mudrajad. 2003. Metode Riset untuk Bisnis \& Ekonomi. Jakarta : Erlangga.

Lubis, Arfan Ikhsan. 2010. Akuntansi Keprilakuaan. Jakarta : Salemba Empat. Jakarta.

Malik, Rahardian. 2010. Analisis perbedaan komitmen profesional dan sosialisasi antisipatif mahasiswa PPA dan Non-PPA pada hubungannya dengan Whistleblowing”. Tesis. Universitas Diponegoro. Semarang.

Melllisa, et, al. 2017. Analisis Faktor-Faktor Yang Mempengaruhi Niat Mahasiswa Melakukan Tindakan Whistleblowing (Studi Pada Mahasiswa Akuntansi Stie Asia Malang). JIBEKA. 11 (1) : 56-63.

Near, J. P., \& Miceli, M. P. 1985, Februari. Organizational dissidence : The case of whistleblowing. Journal of Business Ethics. 4(1): 1-16

Park, et al. 2008. "Cultural Orientation and Attitudes Towards Different Forms of Whistleblowing : a comparison of South Korea, Turkey and the UK". Journal of Business Ethics. 82 (4): 929-939.

Park, dan Blenkinsopp, John. 2009. Whistleblowing as Planned Behaviour - A Survey of South Korean Police Officer. Journal of Business Ethics. 85:545-556.

Parianti, et, al. 2016. Faktor-Faktor Yang Memepengaruhi Niat Dan Perilaku Whistleblowing Mahasiswa Akuntansi. . E-Jurnal Ekonomi dan Bisnis Universitas Udayana.

Pedoman Penulisan Karya Akhir. 2016. Fakultas Ekonomi dan Bisnis Universitas Tanjungpura.

Rhoades, L., \& Eisenberger, R. 2002. Perceived organizational support : a review of the literature. Journal of Applied Psychology. 87 (4): 698-714

Sagara, Yusuf. 2013. Profesionalisme Internal Auditor Dan Intensi Melakukan Whistleblowing. Jurnal Liquidity. 
Saud, Ilham Maulana. 2015. Pengaruh Faktor Individual Dan Faktor Situasional Terhadap Niat whistleblowing Internal-eksternal Dengan Variabel Pemoderasi Persepsi Dukungan Organisasi. Tesis. Universitas Gadjah Mada, Yogyakarta.

Semendawai, et al. 2011. Memahami Whistleblower. Jakarta: Lembaga Perlindungan Saksi dan Korban (LPSK).

Singgih, Santoso. 2007. Buku Latihan SPSS Statistik Parametrik. Jakarta: PT. Eleks Media Komputindo.

Sugiyono. 2013. Metode Penelitian Kuantitatif, Kualitatif dan R\&D. Cetakan ke-19, Oktober 2013. Bandung : CV. Alfabeta.

Sulistomo, Akmal. 2012. Persepsi Mahasiswa Akuntansi Terhadap Pengungkapan Kecurangan (Studi Empiris pada Mahasiswa Akuntansi UNDIP dan UGM). Skripsi. Universitas Diponegoro, Semarang.

Trongmateerut \& Sweeney. 2012. The Influence of Subjective Norms on Whistleblowing: A Cross Cultural Investigation. Journal of Bussiness Ethics. 112 (3) : 437-451.

Wiyono, Gendro. 2011. Merancang Penelitian Bisnis dengan Alat Analisis SPSS 17,0\& SmartPLS 2.0. Yogyakarta : UPP STIM YKPN

Yobapritika, Layli. 2014. Pengaruh Sikap, Norma Subyektif, dan Kontrol Keprilakuan yang Dipersepsikan terhadap Niat Kepatuhan Wajib Pajak di Kota Yogyakarta. Skripsi. Universitas Negeri Yogyakarta. Yogyakarta.

Zhang, et. al.,. 2008. Decision-Making Process of Internal Whislteblowing Behavior in China: Empirical Evidence and Implications. Journal of Business Ethics. 88 : 25-41. 